Nils Kruse:

\title{
Regionplanlægningen \\ - amtskommunen som element i det politisk-administrative system
}

\begin{abstract}
Regionplanlægningen blev den første prøve på det amtskommunale selvstyre. Hvilke vilkår den blev udført under, og hvad resultatet blev, er problemstillinger, der søges belyst i denne artikel. Planlægningen var afhængig af samfundsmæssige og organisatoriske vilkär. Der skulle tages hensyn til mange modsatte interesser. Isar blev der taget hensyn til kommunerne, men ogsả administrative forhold og statslige tilkendegivelser fik betydning. Resultatet blev, at planerne blev meget generelle. Sả regionplanlægningen er mere et eksempel pá selvstyre af navn end af gavn.
\end{abstract}

I 70'erne er der kommet en lang rakke reformer inden for lovgivningen som for eksempel byrdefordelingsreform, planlovreform, socialreform og budget- og regnskabsreform. Forudsætningen for disse reformer var de st $\phi r r e$ administrative enheder, der blev dannet med kommunalreformen.

Målet med disse reformer er dels fors $\varnothing \mathrm{g}$ på en stærkere styring af samfundets fremtidige udvikling, og dels at $\phi g e$ det kommunale selvstyre.

Reformerne indeholder derfor bestemmelser om en decentralisering $i$ den betydning, at magten fordeles på selvstændige, lokale myndigheder. Selvstyret skal finde sted inden for grænser, der er fastsat af Folketing og centraladministration, og hertil er de anvendte midler rammestyring og bloktilskud. Samtidig indføres gennem budgetog regnskabsreformen og planlægningen - her især sektorplanlægningen - et informationssystem, der giver staten direkte indsigt i de lokale forhold, hvorved der åbnes mulighed for statslige indgreb. Modsætningen mellem centralstyring og decentral beslutningstagen er således indbygget $i$ disse reformer fra starten. ${ }^{l}$ I

1) En analyse af dette spørgsmål er foretaget af $\mathrm{M}$. Højland og C.V. Jensen, "Bidrag til en analyse af det kommunale selvstyres stilling i Danmark", Tidsskrift for politisk фkonomi, 5. ảrg., nr. 2 (1978), RUC. 
Nils Kruse:

\title{
Regionplanlægningen \\ - amtskommunen som element i det politisk-administrative system
}

\begin{abstract}
Regionplanlægningen blev den første prøve på det amtskommunale selvstyre. Hvilke vilkår den blev udført under, og hvad resultatet blev, er problemstillinger, der søges belyst i denne artikel. Planlægningen var afhængig af samfundsmæssige og organisatoriske vilkär. Der skulle tages hensyn til mange modsatte interesser. Isar blev der taget hensyn til kommunerne, men ogsả administrative forhold og statslige tilkendegivelser fik betydning. Resultatet blev, at planerne blev meget generelle. Sả regionplanlægningen er mere et eksempel pá selvstyre af navn end af gavn.
\end{abstract}

I 70'erne er der kommet en lang rakke reformer inden for lovgivningen som for eksempel byrdefordelingsreform, planlovreform, socialreform og budget- og regnskabsreform. Forudsætningen for disse reformer var de st $\phi r r e$ administrative enheder, der blev dannet med kommunalreformen.

Målet med disse reformer er dels fors $\varnothing \mathrm{g}$ på en stærkere styring af samfundets fremtidige udvikling, og dels at $\phi g e$ det kommunale selvstyre.

Reformerne indeholder derfor bestemmelser om en decentralisering $i$ den betydning, at magten fordeles på selvstændige, lokale myndigheder. Selvstyret skal finde sted inden for grænser, der er fastsat af Folketing og centraladministration, og hertil er de anvendte midler rammestyring og bloktilskud. Samtidig indføres gennem budgetog regnskabsreformen og planlægningen - her især sektorplanlægningen - et informationssystem, der giver staten direkte indsigt i de lokale forhold, hvorved der åbnes mulighed for statslige indgreb. Modsætningen mellem centralstyring og decentral beslutningstagen er således indbygget $i$ disse reformer fra starten. ${ }^{l}$ I

1) En analyse af dette spørgsmål er foretaget af $\mathrm{M}$. Højland og C.V. Jensen, "Bidrag til en analyse af det kommunale selvstyres stilling i Danmark", Tidsskrift for politisk фkonomi, 5. ảrg., nr. 2 (1978), RUC. 
denne artikel fors $\phi$ ges at give et billede af, hvordan dette nye system har virket, set ud fra det amtskommunale niveau, og med eksempel i regionplanlagningen.

\section{Rollerne ændres}

Før kommunalreformen var der $i$ amtet et embedsmandsstyre. Det var amtmanden -statens lokale representant - der formelt traf beslutningerne. Som formand for byudviklingsudvalget traf han bestemmelser om de større byers bymassige bebyggelse. Efter kommunalreformen er det lokalt valgte politikere, der skal træffe beslutningerne. Med planlovreformen blev det amtsrådet, der skulle fastlægge rammerne for kommunernes udvikling.

Mange politikere tog udgangspunkt $i$ den opfattelse, at embedsmændene havde haft for stor magt. Dette skulle nu andres. Politikerne фnskede lerfor at have kontrollen med og indsigten $i$ enkelt-

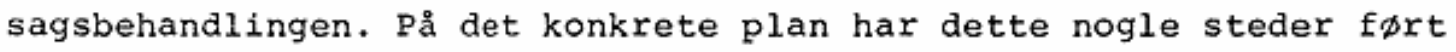
til, at kun forvaltningschefer er til stede ved udvalgsm $\phi$ der, mens afdelingsledere kun er til stede, når sager fra deres eget område er til behandling. Den embedsmand, der har behandlet sagen konkret, er ikke den, der forelægger sagen for udvalget.

Heller ikke politikernes rolle var dog afklaret. Amtsrådsmedlemmerne har vanskeligheder med at overskue, hvad det vil sige at repræsentere hele amtet. Noget af arsagen hertil er valgsystemet. Amtsrådets medlemmer er opstillet lokalt, og mange af dem sidder både $i$ amtsråd og kommunalbestyrelse. Det fører til, at nogle medlemmer åbent erklærer, at de sidder $i$ amtsrådet for at varetage interesserne for den kommune, hvori de har hjemme. Når for eksempel Holbæk kommune kommer med indsigelser mod regionplanen, vil de medlemmer, der hører hjemme $i$ området, fremføre denne kommunes synspunkter, og det ofte uanset den enkeltes partitilhфrsforhold. Andre viser med deres holdninger, og den stilling de indtager $i$ forskellige sager, hvilket lokalområde de hører til. Kun få medlemmer tænker regionalt.

Amtskommunen er en ung organisation, der endnu ikke har fundet sin rolle $i$ det administrative system. Derfor er organisationen usikker på sig selv, ligesom omgivelserne ser med skepsis på den. Mange mener, at den bør nedlægges, og derfor må den træde varsomt. 


\section{Interessemodsætninger}

Amtskommunens handlinger må vurderes ud fra de interessemodsætninger, den indeholder, og som ligger bag dens adfærd. Det er $i$ dette perspektiv, at man må vurdere afgфrelser i enkeltsager eller udf $\phi$ relse af en planlægning. Man må også tage hensyn til, at embedsmænd og politikere ser på de opnåede resultater ud fra, at det er personer, der handler. Det er ikke systemer eller klasser. I dette perspektiv bliver handlinger ofte irrationelle og tilfældige - eller rettere, de får deres egen form for logik, der vanskeligt kan tilpasses generelle teorier.

\section{Samfundsmæssige vilkår}

Regionplanlægningen kan selvfølgelig ikke ses isoleret. Den er blevet til som en del af samfundets historiske udvikling. Det er strukturelle forandringer af samfundet, der har skabt behovet for planlægning. Derfor er regionplanlægningens funktion, form og indhold bestemt af de ideologier, der dominerer i samfundet på et givet tidspunkt.

Loven om lands- og regionplanlægning er udformet ud fra en forestilling om vækst. Det er en forestilling, der også præger regionplanforslagene $i$ dag. For eksempel hedder det $i$ Ringk $\not b i n g$ amtskommunes regionplan:

Det er amtsrådets målsætning, at der også i fremtiden opnås et $\phi k o n o m i s k$ vækst i amtskommunen, og at geografiske skævheder udlignes. (s. 143)

Indf $\phi$ relsen af regionplanlægningen begrundes blandt andet $i$ de uheldige konsekvenser, der har været $f \phi l g e n$ af $60^{\prime}$ ernes byvækst, der har ført til stagnation eller tilbagegang $i$ periferiområder. Det hedder i loven, at planlæqninqen skal ske med henblik på at fremme en ligelig udvikling i lanaet. Det var en bestemmelse, som blev indf $\phi \mathrm{rt}$ af Holger Hansen $i$ sidste $\phi j e b l i k$ for at få tilslutning til loven fra Venstre. I vækstområder har væksten skabt arealkonflikter, hvorfor der blandt andet skal ske en adskillelse af miljøbelastende aktiviteter og beboelse. Regionplanlægning skal handle om en fordeling af den samfundsmæssige vækst, hedder det $i$ bemærkningerne til loven.

60 'ernes teknologiske udvikling førte til, at effektivitet og rationalitet blev de centrale begreber. Derfor er planlægningspro- 
ceduren fastlagt ud fra idealet om den rationelle beslutningsmodel, der indebærer en detaljeret mål-middel-styring og en udstrakt anvendelse af kvantitative metoder. Prognoser og modeller er derfor blevet væsentlige arbejdsredskaber i planlægningen. Planlægningen får skær af en teknisk rationalitet, der giver embedsmænd mulighed for at optræde $i$ en videnskabelig og neutral rolle. En rolle, der ikke holder for en nærmere analyse. ${ }^{2}$

Udviklingen $i$ samfundet bestemmer også de temaer, der får hovedvægten i planlægningsarbejdet. Efter energikrisen i 1973 er levevilkår i stadig stigende grad blevet et emne i planlægningen. I stedet for vækst taler man om, at $i$ disse ressourceknappe tider er tiden inde tilat tale om kvalitative forbedringer af miljфet. Når politikere så villigt tager denne debat óp, kunne man få den mistanke, at det ideologisk er udtryk for, at befolkningen på denne måde lettere accepterer en reallønsforringelse.

\section{Organisatoriske vilkår}

Modsætninger $i$ den amtskommunale organisation er $i$ høj grad bestemmende for regionplanlægningens konkrete indhold. Problemet er, om organisationens struktur er sådan, at den kan afveje forskellige sektorinteresser mod hinanden. Hver sektor varetager f $\phi$ rst og fremmest sine egne interesser. Først derefter ser man på helheden. I for eksempel en sygehusplanlægning tager man udgangspunkt i institutionernes funktion, mens de beskæftigelsesmæssige effekter for et lokalområde ikke indgår i overvejelsen. Problemet bliver om sygehusplanen skal være en forudsætning for regionplanen eller, om den skal underordnes regionplanens mål. På samme måde opstår der konflikter, når der diskuteres grusgravning eller placering af en losseplads $i$ et fredningsværdigt område.

Ligeledes skaber den hierarkiske opbygning modsætninger. Der er formelle regler for, hvem der på forskellige områder har beslutningskompetence. Det giver sig for eksempel udtryk $i$, at det er cfiest kun forvaltningschefer og afdelingsledere, der må underskrive breve. Det er ligeledes dette фverste niveau i hierarkiet, der træffer afgðrelser om, hvad der skal forelægges politikerne.

2) Se f.eks. A. Sandberg, En frăga om metod, 1975; Prisma og M. Castells, City Class and Power, 1978, McMillan Press. 
Menige embedsmænds synspunkter når således kun frem til politikerne, såfremt de er $i$ overensstemmelse med ledernes synspunkter. Eksempelvis vil et notat om regionplanens politiske konsekvenser næppe nå frem til at blive politisk behandlet. Embedsmænd må jo ikke beskæftige sig med politik, til trods for at det spørgsmål politikerne må stille sig er: hvordan tjener denne plan mine vælgere. Det er da også karakteristisk, at regionplanforslagene er så generelle, at de er blevet vedtaget med et flertal $i$ de forskellige amtsråd, der dækker det politiske spektrum fra SF til konservative.

\section{Den amtskomunale selvstændighed}

Den direkte statslige styring sker gennem bekendtgørelser, cirkulærer og landsplandirektiver. Proceduren for tilvejebringelsen af regionplanen har været givet på forhånd. Der skulle fremlægges alternative skitser, selv om det ofte har været vanskeligt at finde flere end koncentration og spredning. Emnerne, der er gengivet $i$ lands- og regionplanlovens $\$ 7$, stk. 1 , er blevet behandlet, mens fa har brugt muligheden $i \$ 7$, stk. 2, om at medtage andre forhold af væsentlig betydning. Endvidere har tidsfrister været bestemmende for, hvor dybt man kunne $g a ̊$ ind $i$ udarbejdelsen af baggrundsmateriale til regionplanlægningen. Endelig er der kun kommet tre direktiver, et der på forhånd lagde ting fast om udpegning af områder til en eventuel placering af kernekraftværker, et om afgrænsning af kystnare områder, og et om areal-reservation til naturgasnettet.

Den statslige styring må siges at have været mild. De enkelte amtskommuner har haft frihed til at udarbejde regionplanen efter egne ideer og i overensstemmelse med lokale forhold, uden at staten direkte har blandet sig. Det skyldes dels usikkerhed fra sta-

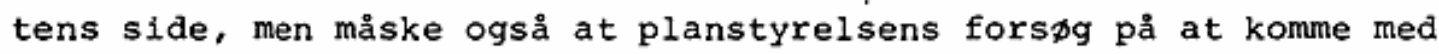
deres synspunkter på de alternative skitser, blev betragtet som utilbørlig indblanding. Over for Vestsjællands amtskommunes alternative skitser blev der af planstyrelsen rejst betænkeligheder ved muligheden for at gennemf $\varnothing$ re to af skitserne: decentralisering og koncentration langs Store Bælt. Det blev sammenlignet med, at en dommer kom med sin kendelse $f \varnothing r$ retssagen var færdig. Dette notat til Vestsjællands amtskommune førte til, at de $\phi$ vrige amtskommuner frabad sig sådanne forelфbige kommentarer, og der, hvor man havde 
modtaget dem, blev de holdt tilbage til efter offentlighedsfasen. Denne holdning skyldes nok mere, at politikerne ikke ville acceptere, at embedsmænd $i$ centraladministrationen skulle bestemme over det, som lokale politikere havde bestemt, end det, at borgerne kunne tage stilling til de statslige synspunkter.

Statslige tilkendegivelser $i$ form af vejledninger og redeg $\phi$ relser bliver $i$ højere grad opfattet som ideer, der kan følges eller ikke f $\phi l g e s$, som det passer til de lokale forhold. Amtskommunen har primært set på, hvor meget - eller snarere, hvor lidt der skal med $i$ regionplanforslaget for, at det kan blive godkendt.

Når alle amtskommuner bygger deres regionplan op omkring et bymønster, kan det tages som et udtryk for, at man har fulgt ideerne $i$ vejledninger og landsplanredegørelser. Det ses også, at næsten alle regner med, at et lokalcenter skal have et opland på 1200 indbyggere. Det er et normtal, der er fulgt uden hensyntagen til de lokale betingelser.

Disse forhold har betydet, at regionplanforslagene $i$ deres emnevalg og deres udformning er forholdsvis ensartede. Der, hvor forskellene træder frem, er $i$ den præcisering, som retningslinierne har fået i forslagene.

Loven skelner mellem redegørelse og retningslinier. Derfor er mange af regionplanforslagene delt $i$ to bind. Denne deling er $i$ Vestsjællands amtskommune så gennemf $\phi r t$, at det kun er retningslinierne, der er vedtaget af amtsrådet, mens redegørelsen er udarbejdet på pkonomiudvaligets foranledning.

Hermed er lagt op til, at processen er vigtigere end en vurdering af planens konsekvenser. Det er vigtigere, at planen kan administreres, end at den skal danne grundlag for en debat.

\section{Regionplanens detaljeringsgrad}

Retningslinierne er regionplanens bindende indhold, hvorfor udformningen af denne har ført til den hidtil skarpeste debat omkring regionplanlægningen. Denne debat blev især ført omkring vejledning nr. $3,^{3}$ der skulle angive, hvor detaljeret regionplanen skulle være. Planstyrelsen gik ind $i$ denne debat med den holdning, at alt, hvad

3) Miljøministeriet, Vejledning i regionplanlagning $n x$. 3, Udarbejdelse af regionplanforslag , 1978 . 
der ikke direkte er forbudt, er tilladt. Dette var en følge af, at vedtagelsen af kommuneplanloven i 1975 førte til, at man gik fra en godkendelsesordning af enkeltsager til en rammestyringsordning. Herefter kan $k$ mmunerne selv besteme arealanvendelsen $i$ deres kommune- og loka.planlægning inden for rammerne af regionplanlægningen. Er der i agen rammer, kan kommunerne gøre, som de vil.

Der kom en konsekvensændring 1 lands- og regionplanlovens §15, stk. 1, hvor det tidligere hed, at "amtsrådets og kommunalbestyrelsernes planlægningsvirksomhed og udf $\varnothing$ relse af anlægsdispositioner ikke måtte stride imod en godkendt regionplan", hedder det nu, at de "i\} ke må stride imod regionplanlægningen".

Dette ska: forstås på følgende måde:

Det kan i den forbindelse bemærkes, at de forarbejder til regionplanforslaget, som amtsrådet fremlægger efter afslutningen af den of centlige debat om de alternative skitser, vil være omfattet af begrebet regionplanlægningen og vil derfor have de ovenfor beskrevne retsvirkninger. Dette yælder også amtsrådets oplæg til forhandling med kommunerne, jvf. loven §13, stk. 1 . (Cirkulæreskrivelse af 18. maj 1978).

Dette vakte en del furore hos amtspolitikerne. Nu var de pludselig i den situation, at de dele af regionplanlægningen, som de på det pågældende tidspunkt havde vedtaget, blev bindende. Ja, der var sågar dele af regionplanlægningen, der ikke var blevet behandlet $i$ amtsrådet, men kun godkendt af planlægningsudvalget ( $\varnothing$ konomiudvalget). Før havde regionplanlægning været uforpligtende - men nu kom deres vedtagelser til at få konsekvenser.

Politikerne huskede ikke, selv om de var blevet gjort opmarksomme på det, at der allerede $i$ bekendtgørelsen af lov om lands- og regionplanlægning 19. september 1975 i en note stod "tidspunktet for ikrafttrædelse af $§ 15$, stk. 1 fastsættes af miljøministeren". Havde politikerne gjort sig klart, hvad det betød, ville oplæggene til regionplanlægningen nok have været endnu blødere formuleret end tilfældet var.

Resultatet af diskussionen omkring vejledning $\mathrm{nr} .3 \mathrm{blev}$, at vejledningen kom til at rumme så mange forhold og så store onsker om data, at det kun vil blive få regionplaner, der kan blive godkendt, såfremt alle ønsker skal opfyldes. Kommunernes Landsforening (KL) havde da også store betænkeligheder ved at acceptere vejledningen. Derfor står der $i$ forordet til den således: 
Der har været forhandlet med de kommunale organisationer fra begyndelsen af arbejdet med vejledningen. Der har selvsagt ikke kunnet opnås fuld enighed på alle punkter. Men der er efter miljøministeriets opfattelse nået en balance mellem de synspunkter, som de kommunale organisationer hver især har gjort gældende, og de hensyn som if $\varnothing$ lge lovens bestemmelser må iagttages.

Et resultat var, at Kommunernes Landsforening talte om alt for stor detaljeringsgrad. Mange af de amtslige kommuneforeninger holdt møder, hvor de søggte at nå en falles holdning til det, der blev betragtet som indgreb $i$ det kommunale selvstyre. Synspunkter var, at der intet var overladt til kommuneplanlægningen. Et synspunkt der starkt prægede de videre forhandlinger om regionplanen.

vejledningen betjener sig af et særligt sprogbrug. Ordet "skal" anvendes til at dække emner, der forlanges behandlet, ordet "kan" til emner, hvor amtsrådet har kompetence til at medtage det, og ord som "hovedregel", "af regional betydning", og lignende for emner, der eventuelt kan behandles i regionplanen. Dette er et sprogbrug, der $i$ udstrakt grad også er anvendt $i$ regionplanforslagenes retningsliniedel.

Som blot et enkelt eksempel kan navnes fra Ribe amtskommunes rẹgionplanforslag:

224. Siloanlæg i større højde end foreskrevet i kommunelandlovgivningen, st $\phi$ rre antennemaster og fritstående vindm $\phi l l e r$ samt andre høje tekniske anlæg må normalt ikke etableres i naturområder.

Hvis man i vejledningen kun hæfter sig ved de steder, hvor ordet "skal" er anvendt, må det siges, at der er ret vide rammer for amtsrådenes muligheder for at udarbejde regionplanforslaget efter egne krav og фnsker. Hvis alle "kan" og "af regional betydning" medtages vil det indebære så snævre rammer, at der med rimelighed kan tales om en stramning. Derfor har regionplanforslagene også for det meste holdt sig til steder, hvor ordet "skal" er anvendt.

\section{Den statslige godkendelse}

Med retten til at godkende regionplanerne har staten muligheden for at afgrænse amts- og primærkommunernes handlingsspillerum. Ligeledes sikrer staten sig information om status og udvikling, ligesom den fastlægger en lang række normer. Så det kan forventes, at der efter 1. generation af regionplaner vil ske en ensretning og op- 
stramning af regionplanerne. Dette vil især ske igennem de krav, der vil blive stillet til tillæg til regionplanen. Muligheden for med hjemmel i \$14 i lands- og regionplanloven at stille krav om tillæg betyder, at de nuværende regionplanforslag næppe kan undgå at blive godkendte. For hermed behøver staten kun at godkende dele af forslagene. Dette vil højst sandsynligt blive tilfældet, da staten ikke, uden at det vil skabe store vanskeligheder med overhovedetat gennemf $\phi r e$ en regionplanlægning, kan nægte godkendelse.

Endnu er kun Bornholms amtskommunes og Hovedstadsrådets regionplanforslag godkendt. I godkendelsesskrivelsen til Bornholms amtsråd ses, at der stilles krav om to tillæg. Ligeledes ses, at staten ikke фnsker at blive bundet af regionplanen i særlig høj grad. I Bornholms regionplan står om statslig virksomhed generelt:

Ved omlokalisering af en statslig virksomhed og evt. lokalisering af ny statsilig virksomhed skal der henses til regionplanens centerstruktur.

Om denne retningslinie hedder det i statens godkendelse:

Ministerier og styrelser har mattet afvise at kunne forpligtes til at disponere som anvist i regionplanforslagets afsnit om statens opgaver.

Derfor er retningslinien overf $\varnothing \mathrm{rt}$ til handlingsprogrammet, der så ikke er omfattet af godkendelsen.

\section{Primærkommunernes muligheder}

Hovedtesen i regionplanarbejdet har for en stor del været: undgå konflikt med kommunerne.

I regionplanforslagene er overskriften på de fleste: decentralisering. Den opfattes som en spredning af byfunktionerne. Dette forklares som et resultat af offentlighedsfasen. Befolkningen gav jo udtryk for, at den фnskede en decentralisering. Det er dog $i$

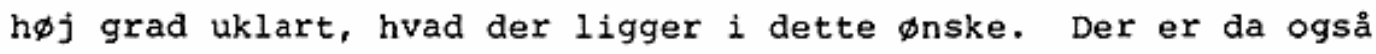
forskel på, hvordan decentraliseringen er udformet $i$ de forskellige amters regionplanforslag. Som årsag hertil peger vejle amtskommune 1 sin "Regionplan 1980" på:

Det er en almindelig forskel mellem regionplanforslaget og offentlighedsfasens indlæg, at regionplanforslaget emnemassigt er mere begrænset end offentlighedsindlæggene. Ligeledes er regionplanforslaget mere generelt regelskabende, mens offentlighedsindlæggene gennemgående stiller meget konkrete forslag. 
Det ses, at regionplanernes hovedlinier er påvirket af borgernes synspunkter. Uden offentlighedsfase ville planerne nok have været mere $i$ overensstemmelse med 60'ernes planlægningsdogme om, at koncentrationen er mere фkonomisk rationelt og effektivt. Derimod er borgernes indflydelse på sektorplanlægningen og enkeltsagbehandlingen begrænset. Her er det de фkonomiske strukturer og sagernes politiske konsekvenser, der tæller. Det er et spørgsmål om, hvilke interesser der er involveret og om styrkeforholdet mellem dem.

Heri kan findes en anden og måske rigtigere forklaring på decentraliseringen. Der er så mange forskellige interesser indblandet, at amtsrådet for at tilgodese alle parter nødvendigvis må fordele ligeligt i hele amtet. Især må amtsrådet være forsigtig med at begunstige nogle kommuner på bekostning af andre.

I Viborg amtskommunes forslag til regionplan hedder det:

Dette vil kræve tilbageholdenhed fra de egne, der i dag har et veludbygget bymønster. Amtsrådet finder det dog ikke hensigtsmæsigt at fors $\varnothing$ ge at begrænse byudviklingen i disse dele af amtskommunen ved en stærk restriktiv politik. Den ændrede fordeling af byudviklingen søges først og fremmest opnået gennem en positiv støtte til de svagere egne.

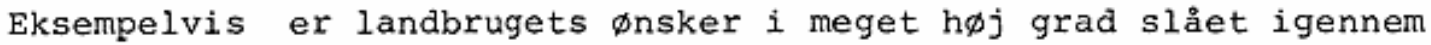
i regionplanerne. "Områder med særlige fredningsinteresser anvendes hovedsagelig til land- og skovbrug. Sådan anvendelse kan fortsætte som hidtil under hensyntagen til fredningsinteresserne", hedder det som retningslinie i Storstrøms amtskommunes Regionplan 1980-92. Den store indflydelse landbruget har fået er følge af en holdningsændring, der er sket $i$ løbet af offentlighedsfasen. Før denne var landbrugsinteresserne forholdsvis lavt prioriteret $i$ forhold til for eksempel fredningsinteresserne.

Industrirådet har ligeledes $i$ et vist omfang fåt de $\phi$ nsker tilgodeset, som det har udtrykt $i$ pjecen "Industrien og den fysiske planlægning". Som retningslinie hedder det $i$ Vestsjællands amtskommunes regionplan:

Regionale erhvervsområder udlægges normalt ved egns- og områdecentre. Ved placeringen af disse områder lægges der vægt på en god trafikal beliggenhed, forsyning med kraft og vand og en veludbygget spildevandsafledning.

Industrirådets syn på at egnscentre - eller som det kalder det, basisbyer - ikke må være mindre end 5.000 indbyggere, er også sam- 
menfaldende med de synspunkter, der er udtrykt $i$ landsplanredeg $\varnothing-$ relserne.

Arbejderbevægelsens erhvervsråd har tilkendegivet en række generelle synspunkter, som ligelig adgang til beskæftigelse og uddannelse og kort afstand mellem bolig og arbejdsplads. Det er synspunkter, der genfindes $i$ regionplanernes overordnede mål. Men samtidig peger de på, at lokalisering af virksomheder skal finde sted $i$ de større byer. Det er et synspunkt, der medvirker til, at Fællesorganisationernes Samvirke i Vestsjalland er kommet med indsigelse mod graden af decentralisering $i$ Vestsjællands amtskommunes regionplan.

Det at tilgodese disse mange interesser har været amtsrådets opgave. Da mange forskellige synspunkter blev udtrykt af befolkningen $i$ offentlighedsfasen er det nemmest, at legitimere regionplanernes udformning ved at henvise til, at den er $i$ overensstemmelse med befolkningens (læs vælgernes) фnske.

\section{Forhandlingsrunder}

Regionplanlægningen har været opfattet som prøven på amtskommunernes berettigelse. Der har da også været en udstrakt grad af samarbejde mellem amtsråd og kommunalbestyrelse. Et samarbejde der uden tvivl har fort til et bedre forhold mellem de to myndigheder, blandt andet som $f \varnothing l g e$ af de mange forhandlinger, der har været ført dem imellem.

Amtsrådets holdning $i$ disse forhandlinger har været præget af, at vi lever $i$ et repræsentativt demokrati. Det betyder, at amtsrådet i højere grad lægger vægt på de folkevalgte råds synspunkter end på tilkendegivelsen fra borgerne. Dermed er forhandlinger med kommunalbestyrelserne vigtigere end en debat med borgerne. Det viser sig ved, at offentlighedsaktiviteter ud over den lovbefalede offentlighedsfase har været meget få. Her ved slutningen af processen er der en udbredt træthed hos både politikere og emkedsmænd over at deltage $i$ offentlige møder om regionplanen. En træthed der nærmest slår over i modvilje.

Planlægningsudvalgets holdning i forhandlingerne har gennemgående været den - som den også har været i møderne $i$ offentlighedsfasen - at de er kommet for at lytte, for at høre synspunkter. Ofte bruges staten til at legitimere forhandlingsoplægget med. Der hen- 
vises til, at man kun $f \varnothing l g e r$ loven. Der citeres fra landsplanredegørelserne. Dermed fremstår amtsrådets holdning som uklar. Udvalget kunne derved tage hensyn til kommunernes synspunkter om de lokale forhold, mens det kunne fastholde hovedlinierne $i$ deres eget oplæg .

Et eksempel herpå har været udvælgelsen af lokalcentre. Her har vejle amtskommune udpeget lokalcentre med følgende forbehold:

Klassificeringen af kommunecentre og lokalcentre må betragtes som forel $\varnothing \mathrm{big}$. Den lokale og kommunale service er som tidligere anf $\varnothing \mathrm{rt}$ overvejende et kommunalt anliggende, og bymønstret vil først kunne fastlægges endeligt i forbindelse med kommuneplanlægningen.

Derimod har Storstrøms og Vestsjællands amtskommuner fastlagt 10kalcentrene som en entydig retningslinie. De er fastlagt efter forhandling med kommunalbestyrelserne ud fra et af amtsrådet udarbejdet oplæg. Men så har der været åbenhed fra amtsrådets side med hensyn til ændringer, som kommunalbestyrelserne har фnsket. Dvs. at det endelige resultat er godkendt af kommunerne.

Men om denne godkendelse dækker over en reel enighed vil først vise sig ved kommuneplanlægningen. I hvor høj grad vil kommunerne efterleve de tildelte byggekvoter, og hvordan vil de fordele den på de enkelte centertyper? Hertil kommer fordelingen af kommunale centerfunktioner osv. Dette vil være nogle af de spørgsmål, der skal tages stilling til ved kommuneplanlægningen.

Hvor snævre rammerne er vil vise sig $i$ kommuneplanlægningen. Her vil det nok af borgerne blive opfattet som en begrænsning, idet deres mulighed for at pege på lokalcentre er begrænset. Lokalcentrene vil indgå som en forudsætning, og er ikke lagt åbent ud $i$ den kommende debat omkring kommuneplanlægningen. Borgerne får herved kun mulighed for at komme med indsigelser enten mod regionplanen eller senere mod kommuneplanen.

Et svar på, $i$ hvor høj grad regionplanlægningen begrænser det kommunale selvstyre, kan næppe gives, før den konkrete planlægning skal gennemføres. Meget afhænger af styrkeforholdet mellem amtsråd og kommunalbestyrelser. Hvilken stilling vil amtsrådet tage, hvis en kommunalbestyrelse ikke efterlever regionplanen? Det vil blandt andet afhænge af, om der $i$ amtsrådet kan opnås enighed om at $f \varnothing l g e$ regionplanens retningslinier. 


\section{Den amtskommunale organisation}

Siden 1970 har amtskommunen som organisation været i vækst. Mange nye opgaver er blevet tilført $i$ decentraliseringens navn. Behovet for personale og фkonomiske ressourcer er фget i takt med opgavernes antal, og organisationen er blevet presset både udefra og indefra. Sammen med strukturelle forandringer i samfundet har det ført til, at de ideer politikere og embedsmænd gjorde sig, da de gennemførte kommunelreformen ikke er blevet opfyldt.

Konsekvensen er, at ved indgangen til 80'erne har man en organisation, der er formet ud fra 60'ernes forestilling om stadig vækst, men kravet $i$ dag er vækstbegrænsning. Organisationens struktur og samfundets struktur er kommet ud af balance.

Organisationen må derfor forandre sig. Men det er det offentliges hierarkiske system dårligt egnet til, fordi beslutningskompetence og indsigt med bevægelser $i$ organisationen er samlet $i$ hierarkiets $\phi$ verste niveauer. Et $\phi$ get pres f $\phi$ rer derfor til flere regler, mere kontrol og større centralisering. "Menige" medarbejderes mulighed for at udtale sig til pressen bliver begrænset. Flere enkeltsager skal forelægges de politiske udvalg. Samarbejdsudvalg bliver anset som værende besværlige.

Den store stigning i personale har bureaukratiseret forvaltningerne - stadig flere afdelinger skal hører $i$ behandlingen af en sag. De nye opgaver har $\phi g$ et antallet af eksperter, hvilket har gjort forvaltningsområderne mere tekniske. Dermed får faglige og egne interesser en væsentlig indflydelse på den måde, hvorpå organisationen handler. Eksperter onsker selv at kontrollere, eller at kontrollen kommer fra eksperter inden for samme område. Herved kommer de $i$ konflikt med dels de gældende regler og dels med eksperter fra andre områder.

Disse udviklingstendenser medvirker til at politisere planlægningen. Det mærkes umiddelbart $i$ sektorplanlægningen. Det er her de overordnede mål får en konkret udformning. En beskæring af den offentliges budget mærkes som en begrænsning $i$ anlægsaktiviteterne. Der kommer mangel på plejehjemspladser med lange ventelister til følge. Sygehusaktiviteterne kan ikke udvides, og resultatet bliver manglende effektivitet. Der фnskes en omlægning af de фkonomiske ressourcer, hvorfor der foreslås ændringer i de mindre sygehuses funktion. Befolkningen stiller krav til politikerne ud fra enkelt- 
interesser. Baggrunden kan være nedlæggelse af den lokale skole,

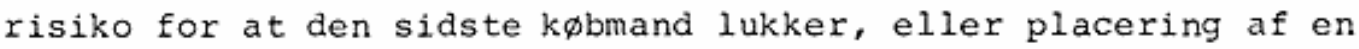
forurenende virksomhed. De politiske problemer $\not g e s$ som konsekvens heraf. Planlægningsinitiativer bliver pludselig til politiske "sager". "Byggeren" i København og PVC-fabrik ved Skælskør er eksempler herpå.

Hvis tilmed det politiske flertal er ustabilt, skærpes kravet om politisk kontrol. En konsekvens heraf bliver, at antallet af sager på dagsordenen for de stående udvalgs møder vokser, politikernes arbejdsbyrde vokser voldsomt, og embedsmændene $\mathrm{f} \not l e r$, at deres arbejdsområde indsnævres. Muligheden for at administrationens behandling af de konkrete sager skal skabe politiske problemer, fører til et $\varnothing$ nske om større indsigt med denne sagsbehandling hos de ledende $i$ det administrative hierarki. Der oprettes for eksempel en central journal. Dvs, at alt materiale, der går ind og ud af administrationen, bliver registreret samme sted. Det er en centralisering, der fører til en følelse af indgreb hos de menige embedsmænd.

Det giver usikkerhed og utilfredshed, og administrationen kommer til at fungere dårligere. De indre hierarkiske modsætninger bliver til konflikter, og det at løse organisatoriske problemer bliver det vigtigste.

Sagerne hober sig op, og for hurtigt at få bunken til at blive mindre er det nemmest at $f \varnothing l g e$ de normdannende og regelsættende statslige cirkulærer, bekendtgørelser osv., der i en stadig strøm tilflyder forvaltningerne. Hos amtskommunen $\varnothing$ ges denne tilbøjelighed yderligere som $f \phi l g e$ af et pres fra kommunerne. Embedsmændene, og også politikerne, legitimerer deres handlinger ved henvisning til, at de kun opfylder lovens krav. Man laver ikke regionplanlagning, fordi man selv synes om det, men fordi Folketinget har bestemt det. Eksempelvis indledes alle regionplanforslag med henvisning til lands- og regionplanloven.

Det at gøre sig overvejelser over at føre en politik på egne betingelser bliver en mangelvare.

Siden regionplanlægningens start i amtskommunerne i 1973-74 er den blevet mere og mere konkret og bindende. Interessemodsætningerne er $i$ løbet af denne proces blevet stadig mere åbenbare. På det politiske niveau er det en udbredt opfattelse, at planlægning er indgreb $i$ den personlige frihed. Det er en holdning, der afspejler sig $i$, at 
mange af regionplanens mål og retningslinier formuleres $i$ brede vendinger. Regionplanlægningen betyder også begrænsninger $i$ de områder, hvor de politiske udvalg kan træffe deres egne skønsmæssige afgørelser. Derfor ses for eksempel, at udvalget for teknik og mil$j \varnothing$ mod sædvanlig praksis og mod forvaltningens indstilling, tillader en virksomheds udvidelse $i$ landzonen. Derfor er det et udbredt politisk фnske - et фnske der følges op af dele af administrationen - at antallet af konkrete retningslinier i regionplanen bliver så få som muligt. Dette afspejler sig i regionplanernes sektcrretningslinier. For eksempel har storstrøms amtskommuner ikke et afsnit for sygehus- og gymnasieplanlægning.

Planlægning er et nyt område, der kræver nye rutiner $i$ forhold til den traditionelle sagsbehandling. Det giver usikkerhed med hensyn til, hvordan man skal løse opgaverne. Derfor betragtes sagsbehandlingen som vigtigere end planlægningen. Det overlades dermed til planlæggerne at opstille de politiske mål for regionens fremtidige udvikling.

- Inden for organisationen har der været problemer med at indplacere regionplanlægningen. Da den er sammenfattende går den på tværs af den hierarkiske opbygning. Sammenfatningen betyder, at den skal koordinere sektorernes planlægning, og dermed også dens konkrete behandlinger. Det sætter selvfølgelig nogle bindinger på sektorernes handlingsspillerum. Kompetence til at afveje de forskellige interesser bliver da af betydning for en regionplans indhold. Det samtidig med, at de enkelte sektorer ser deres eget område som det væsentligste.

Fordelingen af magtressourcer bliver da afgørende for resultatet af de forhandlinger, der er ført med sektorerne om, hvad der skal stå i regionplanens retningslinier. Magtressourcerne kan være at henvise til formelle regler, at udnytte den information man er $i$ besiddelse af, og at fastholde sin faglige ekspertise inden for eget område. I forhandlingsspillet kan man forbedre sin position ved at henvise til, at sagen endnu ikke er forelagt det politiske udvalg eller godkendt af forvaltningschefen. Man kan derfor ikke videregive oplysninger til brug for andre sektorers planlægning, før det er sket.

Alt $i$ alt betyder det, at administrationen ikke er passiv i forhold til indholdet af planlagningen. Det overlades ikke kun til det 
politiske niveau at træffe beslutninger om organisationens mål. Embedsmændenes egne politiske holdninger er også en vigtig faktor. Embedsmænd er ikise neutrale og værdifri i de beslutningsgrundlag, de udarbejder tii politikerne, sådan som traditionen byder dem at være det. Derfor medvirker embedsmændene til at give regionplanlægningen en ideologisk karakter. For eksempel udtrykkes en retfærdigheds- og lighedsforestilling i følgende fra Vestsjællands amtskommunes regionplanredeg $\varnothing$ relse:
I ethvert land findes en lang række love, som gælder for alle landets indbyggere, og som giver dem nogle rettigheder og på- lægger dem nogle pligter .... Egentlige love såvel som uskrevne regler har stor betydning for den enkelte borgers levevilkår. Alle disse samfundsbetingede forhold er givne, og det er inden for disse rammer, at regionplanen skal sфge at forbedre levevil- kårene.

Den langsigtede planlægning, som regionplanlægningen er, skulle netop være udtryk for det lokale folkevalgte råds egen formulerede politik. Friheden til i en dialog med befolkningen selv at bestemme over egen fremtid begrænses blandt andet af, at befolkningen ikke kan se politikernes synspunkter, af at den ikke forstår deres afgørelser. Den begrænses også af, at planlægningsinitiativer ikke ses som en helhed, men som enkeltfænomener. Dette fører til, at overordnede myndigheder $i$ højere grad er $i$ stand til at udnytte deres beføjelser til at koordinere. Så om amtskommunerne alligevel har haft mulighed for at udarbejde regionplanerne på egne vilkår, er meget tvivlsomt. Begrænsninger, der er sat af befolkning, organisationer, kommuner og stat, har $i$ hvert fald gjort et lokalt selvstyre meget vanskeligt. 